BBA $4 I I 6$

\title{
STEREOSPECIFICITY OF THE TRANSPORT OF TERT.-LEUCINE
}

\author{
HALVOR N. CHRISTENSEN, JANE B. CLIFFORD AND DALE I. OXENDER \\ Department of Biological Chemistry, The University of Michigan, Ann Arbor, Mich. (U.S.A.)
}

(Received January $25^{\text {th, }}$ I963)

\section{SUMMARY}

I. Carboxyl-labeled tert.-leucine (pseudoleucine) has been synthesized by the reaction of pivaldehyde with $\mathrm{K}^{14} \mathrm{CN}$, and the stereoisomers separated.

2. About $3 \%$ of the radioactive carbon injected into the rat in the form of the $\mathrm{L}$ isomer is excreted in a volatile form, presumably as ${ }^{14} \mathrm{CO}_{2}$. About $\mathrm{I} \%$ of the ${ }^{14} \mathrm{C}$ of the $\mathrm{D}$ isomer has the same fate.

3. Evidence for substantially higher affinities for renal tubular transport in the rat and in the dog of L-tert.-leucine than of the $\mathrm{D}$ isomer has been obtained. No radioactive metabolite of the $\mathrm{L}$ isomer was detected in the urine of the dog. The results emphasize the possibility that, according to the time interval of urine collection selected, either stereoisomer of an unmetabolizable solute might be isolated unmodified from the urine after administering the DL form.

4. The $\mathbf{L}$ isomer has a much higher affinity for transport into the Ehrlich ascitestumor cell than the $\mathrm{D}$ form, these relationships resembling those for ordinary metabolizable amino acids. tert.-Leucine shows an unusually high specificity for the leucinepreferring transport mediation, relative to the alanine-preferring mediation for neutral amino acid transport; it is therefore recommended for use in the study of these systems in comparative isolation from each other.

\section{INTRODUCTION}

KNOOP AND OKADA ${ }^{1}$ recorded in 1923 that when they fed DL-tert.-leucine ${ }^{\star},\left(\mathrm{CH}_{3}\right)_{3} \mathrm{C}$ $\mathrm{CH}\left(\mathrm{NH}_{3}{ }^{+}\right) \mathrm{COO}^{-}, 6 \mathrm{~g}$ on each of two successive days, presumably to a dog, they could isolate the levorotatory isomer from the urine as its $p$-toluenesulfonyl derivative, which has a specific rotation $+47.75^{\circ}$ in alcohol. Accordingly they concluded that the dextrorotatory component had been destroyed. DAKIN ${ }^{\mathbf{2} 3}$ in $\mathbf{1 9 3 6}$ however, recovered unchanged in the urine as much as $58 \%$ of a $2-\mathrm{g}$ dose of DL-tert.-leucine injected into rabbits.

Eight years later ABDERHALDEN, FAUST AND HAASE ${ }^{4}$ resolved synthetic DL-tert.leucine by the use of brucine. Only the form that is levorotatory in water solution was tested by injection into a dog. A significant part of it was recovered from the urine unchanged, again as the p-toluenesulfonyl derivative. The authors concluded, taking into account also the work of KNOOP AND OKADA, that the other, dextro-

\footnotetext{
* The abbreviation tevt-leucine is used here for this substance, also known as pseudoleucine.
} 
rotatory, isomer is the one accessible to catabolic attack, and hence that it belongs to the $\mathrm{L}$ series. The assignment to it of the $\mathrm{L}(+)$ configuration was supported by the apparently somewhat greater susceptibility to tryptic cleavage of the isomers of $\alpha$-bromotrimethylpropionyl-L-tyrosine and $\alpha$-bromotrimethylpropionyl-tert.-leucine that had been derived from the dextrorotatory tert.-leucine. The investigators also showed that tert.-leucine could be converted to the $\alpha$-bromo derivative by NOBr, and this product then reaminated with $\mathrm{NH}_{3}$, without extensive over-all change of rotation.

Subsequently SNYDER AND CORLEY 5 showed that DL-tert.-leucine largely escapes attack in the dog, as indicated by the failure of the urea excretion to rise, and by the recovery of a large amount of amino nitrogen from the urine. MILLIGAN ${ }^{6}$ with CORLEY repeated this demonstration for the two separated stereoisomers of the amino acid. These results removed all force from the animal experiment of ABDERHALDEN et al. ${ }^{4}$, since either isomer would be expected to be largely excreted into the urine after injection. These findings also support DAxIn's conclusion, but they make the result of KNOOP AND OKADA ${ }^{1}$ hard to explain.

In I953 Izumiya, Fu, Birnbaum and Greenstein ${ }^{7}$ found that the amide of levorotatory tert.-leucine is slowly split by an amidase from hog kidney, whereas the amide of the dextrorotatory form is not. Since only $L$ amidases had been found in animal tissues, they concluded, in contradiction to ABDERHALDEN et al. ${ }^{\mathbf{4}}$, that the levorotatory amino acid has the $\mathrm{L}$ configuration. These authors pointed out that the Lutz-Jirgensons rule supports their conclusion. They also noted the likelihood that ABDERHALDEN et al. ${ }^{4}$ had obtained two successive inversions, one by the action of $\mathrm{NOBr}$ on tert.-leucine, and a second on the reamination of the bromoacid. This course of events could explain the preference of trypsin among the isomers of $\alpha$-bromo$\beta$-trimethylpropionyltyrosine.

Because of its highly branched sidechain we felt that tert.-leucine would probably be useful for studying one particular mediating system for amino acid transport. In addition we were interested in the possibility that a fractionation of the isomers during renal tubular resorption might help to account for the observation of KNoop AND OKADA.

The synthesis of tert.-leucine introduced by KNOOP AND LANDMANN ${ }^{9}$ from acetone, via pinacol, pinacolone, trimethylpyruvic acid and its oxime, promised to be expensive in terms of radioactive carbon. Therefore a Strecker synthesis from pivaldehyde and $\mathrm{K}^{14} \mathrm{CN}$ was developed. The product was resolved according to ABDERHALDEN et al. ${ }^{4}$. The susceptibility of the two isomers to metabolic attack in the rat, their rates of excretion, and their transport behavior in simpler systems, are also reported in this communication.

\section{EXPERIMENTAL}

\section{Synthesis and resolution of DL-tert.-leucine}

$32.5 \mathrm{mg}$ each of $\mathrm{K}^{14} \mathrm{CN}$ ( $5 \mathrm{mC}$; New England Nuclear Corp.) and of unlabeled $\mathrm{KCN}$, plus $53.5 \mathrm{mg} \mathrm{NH}{ }_{4} \mathrm{Cl}$, were weighed into a small test tube. Then $0 . \mathrm{I}_{4} \mathrm{ml}$ (I.20 mmoles) of pivaldehyde (Columbia Organic Chemical Co.) and $0.2 \mathrm{ml}$ water were added, and the mixture agitated. Finally $0.6 \mathrm{ml}$ of methanol was added to dissolve the aldehyde, the tube sealed, and the suspension of crystals shaken vigorously for $10 \mathrm{~min}$ at room temperature, and for $20 \mathrm{~min}$ after placing in a hot water 
bath at $80^{\circ}$. After $4 \mathrm{~h}$ at $80^{\circ}$, the tube was opened, a large excess of concentrated $\mathrm{HCl}$ added, and the solution refluxed for $3 \mathrm{~h}$, the conditions being adjusted to permit considerable loss of volume by evaporation at first to remove methanol. The hydrolysate was freed of excess $\mathrm{HCl}$ by careful evaporation, and the dry residue extracted five times with $\mathrm{I} 5-\mathrm{ml}$ portions of ether-ethanol (2:I) mixture. An aqueous solution of the extracted material was titrated to $\mathrm{pH} 6$ to 6.5 with Amberlite IR-4B resin in the free base form. The filtrate and washings were combined and this solution taken to dryness. The product was crystallized and recrystallized from alcohol-water (I:I) mixture, the mother liquors each being reworked twice by crystallizing unlabeled tert.-leucine from them. The product was chromatographically pure, showing the same $R_{F}=0.75$ obtained for tert.-leucine synthesized from trimethylpyruvic acid, using the solvent mixture, tert.-butanol-formic acid-water (70:15:I5). In the solvent mixture, $n$-butanol-methylethyl ketone-8 $\mathrm{N} \mathrm{NH}_{3}$ (70:I5:I5) both $R_{F}$ values were o.I6.

Serious losses were encountered in recrystallizing to eliminate ammonium chloride from the preparation. Therefore this preparation was purified at the stage of the $\mathrm{N}$-formyl derivative ${ }^{4}$. Most of the contaminating $\mathrm{NH}_{4} \mathrm{Cl}$ was thereby eliminated through its low solubility in alcohol. The radiologic yield under these conditions was $20 \%$ at the stage of $N$-formyl-DL-tert.-leucine, m.p. 208-210 (from water). ABDERHALDEN et al. recorded $210^{\circ}$.

A larger-scale preparation (o.I mole of each reactant) was made using unlabeled $\mathrm{KCN}$. The proportion of ether in the ether-alcohol mixture was increased to $80 \%$ by volume, and the extracted material taken up in a small volume of ethanol, so that the amino acid hydrochloride was dissolved but most of the $\mathrm{NH}_{4} \mathrm{Cl}$ excluded. After neutralizing with Amberlite IR-4B the amino acid was crystallized, first from $50 \%$ ethanol and then from water. (Found: $\mathrm{C}, 54.8 ; \mathrm{H}, 9.9 ; \mathrm{N}, \mathbf{I} 0.8 \% . \mathrm{C}_{6} \mathrm{H}_{13} \mathrm{NO}_{2}$ requires $\mathrm{C}, 54.9 ; \mathrm{H}$, I0.0; $\mathrm{N}$, I0.7\%.)

The resolution of the labeled product was carried out as described by ABDERHALDEN et al., except that 2 successive small portions of the brucine salt of $\mathrm{N}$-formyl$\mathrm{D}(+)$-tert.-leucine were dissolved by warming in the mother liquor from which the corresponding labeled compound had crystallized, and 2 additional crops of crystals taken. The $N$-formyl derivatives, and the free $\mathrm{D}$ - and L-tert-leucines were separated and crystallized ${ }^{4}$ again using the corresponding unlabeled compounds to increase the recoveries. Losses of ${ }^{14} \mathrm{C}$ were small under these conditions. The run on the unlabeled preparation from privaldehyde gave values for $[\alpha]_{D}^{25}$ of +9.4 and $-9.6^{\circ}$ ( $\mathrm{I} \%$ in water) for the $\mathrm{D}$ and $\mathrm{L}$ forms. These correspond, within the accuracy of our determinations, with published values:

\section{Test of metabolism and excretion in the rat}

I $\mathrm{mg}(0.5 \mu \mathrm{C})$ of each isomer in $0.5 \mathrm{ml} 0.9 \% \mathrm{NaCl}$ solution was injected subcutaneously into each of two female rats weighing about $50 \mathrm{~g}$. The animal was then kept for $6 \mathrm{~h}$ in a glass container through which air was swept. This air was subsequently passed through two columns containing Hyamine hydroxide solution to trap respiratory $\mathrm{CO}_{2}$, as described previously ${ }^{10}$. The animal was returned to this apparatus for a 4 -h interval beginning $24 \mathrm{~h}$ after injection. Urine was collected to represent the first and second 6 -h interval, the following three $\mathrm{r} 2 \mathrm{-h}$ intervals, and the third day after injection. A momentary exposure to ether vapors was used to stimulate urination 
at the termination of a collection period. Feces were collected separately. The animals were provided with water ad libitum, and with Rockland rat pellets, with precautions to minimize contamination of the excreta, for brief intervals at the beginning of the second and third days. The counting of radioactive disintegrations in the several samples was carried out as described ${ }^{\mathbf{1 0}, 11}$. The comparison was repeated with almost identical results.

\section{Test of excretion rate in the dog}

$50 \mathrm{mg}$, representing about $4 \mu \mathrm{C}$ of each isomer, were dissolved in $\mathrm{I} \mathrm{ml} 0.9 \% \mathrm{NaCl}$ and injected, first the $\mathrm{D}$ form, and then 5 days later the $\mathrm{L}$ form, into a $6 \mathrm{-kg}$ mongrel bitch. The urinary radioactivity arising from the first test had fallen to 78 counts $/ \mathrm{min}$ excreted per $h$ before the second injection was made. Urine was collected in five intervals by an indwelling Foley catheter for the first $\mathrm{I} 2 \mathrm{~h}$, rinsing the urinary bladder on each occasion. Subsequent urine collections for intervals of $48 \mathrm{~h}$ or less were completed by catheterization. Chromatography on paper, using tert.-butc nol-formic acid-water (70:I5:I5), of urine collected after injecting the $\mathrm{L}$ isomer showed the amino acid fed as the only clearly distinguishable excretion product. The animal had access to food and water throughout the study.

\section{Test of uptake by isolated Ehrlich ascites-tumor cells}

The cells were propagated and collected as usual12. The uptakes of the isomers of tert--leucine were compared at I-mM levels in $4 \%$ suspensions of the cells in KrebsRinger bicarbonate medium. Competitive effects of the amino acid were tested using a $5-\mathrm{mM}$ level acting on a I-mM level of another amino acid. The incubation at $37^{\circ}$ was interrupted by pouring the suspension into an equal volume of the ice-cold medium. Cells were centrifuged $3 \mathrm{~min}$ at about $4^{\circ}$, and the separated cells extracted by holding a suspension for $2 \mathrm{~min}$ in ro volumes of o.or $\mathrm{N}$ acetic acid at $100^{\circ}$. Radioactive disintegrations of $0.2-\mathrm{ml}$ portions of the extracts and of the supernatant solutions were counted as usual ${ }^{10,11}$. To determine apparent $K_{\mathrm{m}}$ and $K_{1}$ values, the inhibitor, namely the $\mathrm{D}$ isomer, was set at a $20-\mathrm{mM}$ level, and the concentration of the $\mathrm{L}$ isomer varied.

\section{RESULTS AND DISCUSSION}

In a preliminary test on the Ehrlich cell, with non-radioactive samples of the $\mathrm{D}$ and $\mathrm{L}$ isomers prepared by MILLIGAN ${ }^{6}$ and kindly given to us by Dr. R. C. Corley, the usual difference in transport affinity was indicated by the much larger inhibitory action of one of the isomers on valine transport (Table I). This isomer to our momentary surprise, was the one labeled $\mathrm{D}(-)$, ABDERHALDEN's assignment of configuration having not yet been questioned at the time of its preparation. This result quickly brought our attention to the correction of the assignment by IzUmIYA et al. ${ }^{7}$. The inhibition of the transport of valine and leucine, combined with the failure to inhibit the transport of alanine or of $\alpha$-aminoisobutyric acid (Table I), shows that this model amino acid migrates by one of the two distinguishable mediating systems, the so-called leucine-preferring mediation ${ }^{8,15,16}$, with a smaller amount of affinity for the related alanine-preferring mediation than has been shown by any naturally occurring amino acid.

The lower section of Fig. I shows, as a typical result, the substantial difference 
in the rates of urinary excretion of the two isomers in the rat, a much larger fraction of the levorotatory isomer persisting in the animal at all stages. Fecal excretion of this amino acid, like that of I-aminocyclopentanecarboxylic acid ${ }^{\mathbf{1 1}}$, was appreciable

TABLE I

INHIBITORY ACTION OF THE ISOMERIC tert.-LEUCINES ON THE UPTAKE OF other amino acids by THE Ehrlich Celi.

The designations of configuration of tert.-leucine follow IzUMry et al. ${ }^{2}$ and correspond to the directions of optical rotation in water solution.

\begin{tabular}{lcc}
\hline $\begin{array}{c}\text { Test amino acid } \\
\text { at } \mathrm{mM}\end{array}$ & $\begin{array}{c}\text { tert.-Leucine inhibitor } \\
\text { at } 5 \mathrm{mM}\end{array}$ & $\begin{array}{c}\text { Distribution ratio } \\
\text { afte' } \mathrm{I} \text { min }\end{array}$ \\
\hline $\begin{array}{l}\text { L-Valine } \\
\text { L-Valine }\end{array}$ & None & 1.30 \\
L-Valine & $\mathrm{D}$ & 1.05 \\
L-Leucine & $\mathrm{L}$ & 0.50 \\
L-Leucine & None & 2.00 \\
L-Leucine & $\mathrm{D}$ & $\mathrm{I} .97$ \\
L-Alanine & $\mathrm{L}$ & $\mathrm{I} .33$ \\
L-Alanine & None & 2.15 \\
$\alpha$-Aminoisobutyric & L & 2.17 \\
$\alpha$-Aminoisobutyric & None & 0.63 \\
& L & 0.63 \\
\hline
\end{tabular}

(about $3 \%$ for the $\mathrm{L}$ form, $6 \%$ for the $\mathrm{D}$, in the first day). The $6-\mathrm{h}$ intervals of urine collection, selected for technical reasons, are less satisfactory than the shorter intervals used below for a dog. The upper part of Fig. I shows that about $3 \%$ of the radioactivity of the $L$ isomer was volatilized by the animal, in a form, from the means of

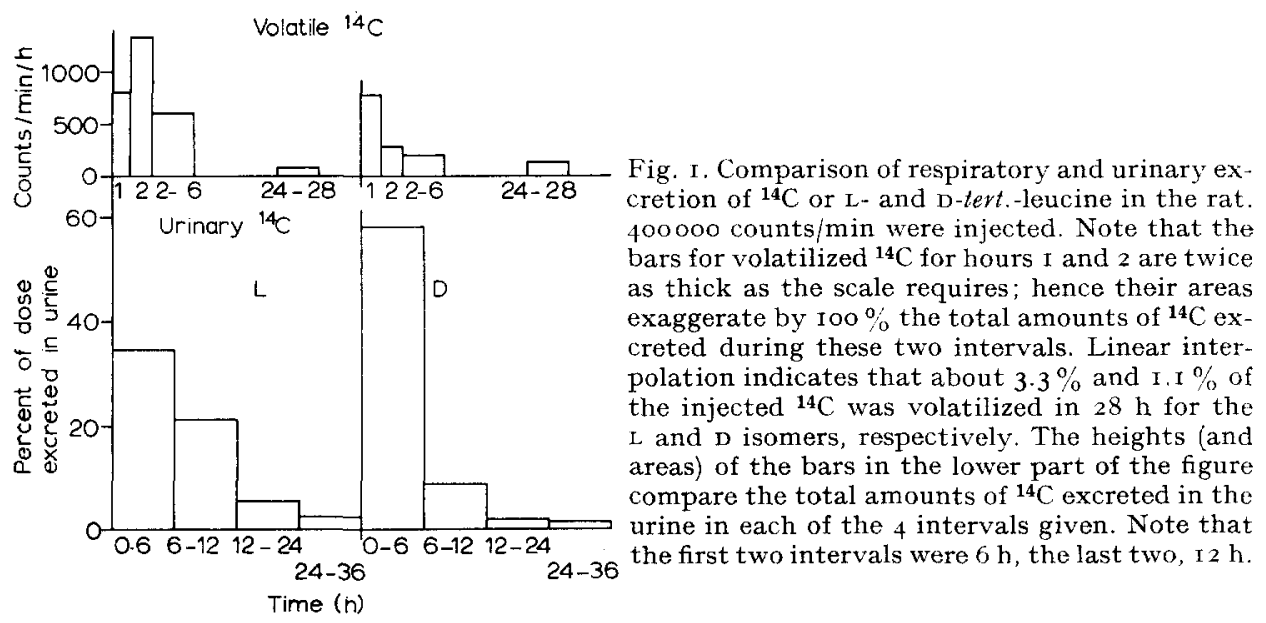

collection, presumed to represent ${ }^{14} \mathrm{CO}_{2}$. The finding that only one-third as much ${ }^{14} \mathrm{C}$ was volatilized from the $\mathrm{D}$ isomer as from the $\mathrm{L}$ (Fig. I) is only partially explained by the smaller amount of this isomer persisting in the animal, since in other tests the contrast was nearly as large the first $2 \mathrm{~h}$ as it was later. 
Fig. 2 shows that L-tert.-leucine is retained by the dog considerably longer than the $\mathrm{D}$ isomer, presumably because of a higher affinity for renal tubular resorption. Whereas $66 \%$ of the $\mathrm{D}$ form was lost into the urine in $3 \mathrm{~h}$, only $\mathrm{I} 2 \%$ of the $\mathrm{L}$ isomer was lost in the same time. From Fig. 2 one can deduce that either the D or the $\mathrm{L}$ isomer might be isolated from the urine of the dog, if appropriate intervals were selected for collection of urine, or if any early urine sample were to be lost. If roo mg of DL-tert.leucine had been injected, the material excreted in the first $3 \mathrm{~h}$ would presumably have been $85 \% \mathrm{D}$; the material remaining in the animal after $6 \mathrm{~h}$ would presumably have been $82 \% \mathrm{~L}$.

An analysis of the serum level of L-tert.-leucine at $7.5 \mathrm{~h}$ after injection yielded, by comparison with the urinary loss from 6 to $9 \mathrm{~h}$, a value for the renal clearance of $2.6 \mathrm{ml}$ of plasma/min. The glomerular filtration rate for this animal should be somewhat more than Io times this value ${ }^{13}$. Even in the unlikely case that the $\mathrm{D}$ isomer had been entirely restricted to the extracellular compartment, its excretion rate corresponds to clearances of $3.2-4.5 \mathrm{ml} / \mathrm{min}$. The actual clearance was undoubtedly much higher. At $7.5 \mathrm{~h}$ the $\mathrm{L}$ isomer had reached a calculated average concentration in the body water over twice that found in the plasma.

The biological half-time calculated from urinary excretion rates during the three intervals between 3 and $\mathrm{I} 2 \mathrm{~h}$ after injection was about $3 \mathrm{~h}$ for the $\mathrm{D}$ isomer and about $\mathrm{I} 2 \mathrm{~h}$ for the $\mathrm{L}$ form. The half-time for the latter isomer retained this approximate value for $30 \mathrm{~h}$, but in the later stages of excretion an apparent half-time of about $22 \mathrm{~h}$ was observed. This later slowing of excretion may well have arisen from moderate elevations of the urinary pressure, since spontaneous voiding did not occur at this stage. Nevertheless we cannot be entirely sure that the unexcreted portion remained entirely in its initial form, even though no other form was observed in

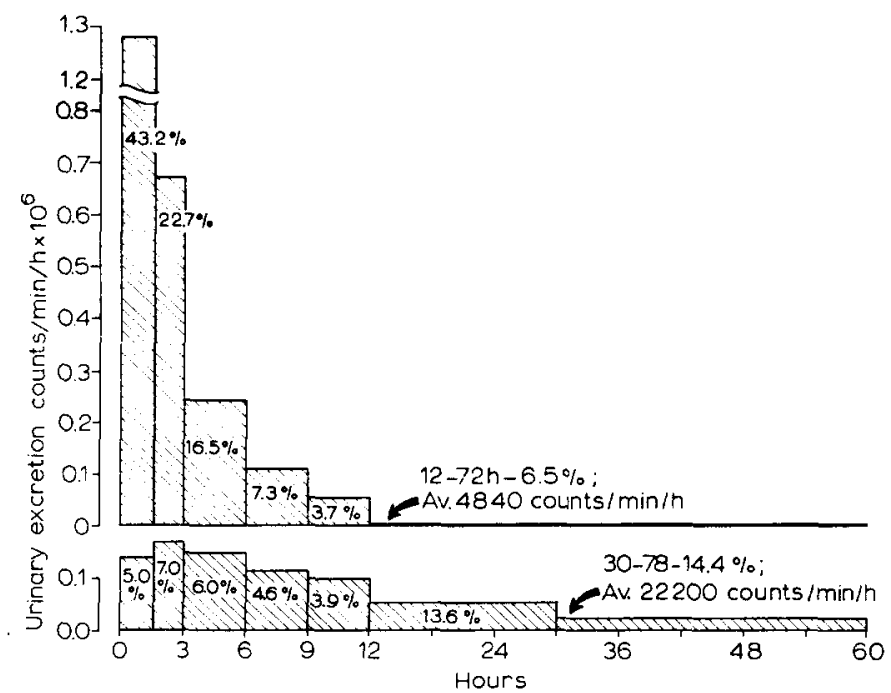

Fig. 2. Comparative rates of excretion of (above) $\mathrm{D}$ - and (below) L-tert.-leucine in a dog. A 6-kg dog received $50 \mathrm{mg}$ of the $\mathrm{D}$ isomer equivalent to $4.4 \cdot 10^{8}$ counts $/ \mathrm{min}$, and 5 days later, $50 \mathrm{mg}$ of the $L$ isomer, representing $3.70 \cdot 10^{6}$ counts/min. The height of the bars compares the hourly rates of excretion, whereas the figures in the rectangles show the percentage of the total excreted in the indicated intervals. Note that the hour scale for the first $12 \mathrm{~h}$ has been expanded to twice the space applying for the subsequent $12 \mathrm{~h}$. 
the urine. In contrast the half-time for the $\mathrm{D}$ isomer remained essentially constant until over $99 \%$ of the total radioactivity had been excreted.

Fig. 3 shows the time-course of the uptake of the two isomeric tert.-leucines by the Ehrlich ascites-tumor cell. Typically, the uptake of the L isomer is essentially

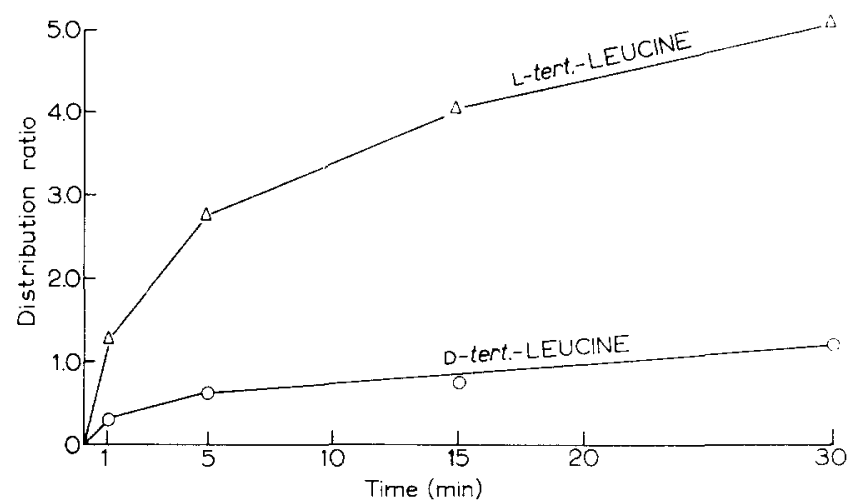

Fig. 3. Time course of the uptake of the isomers of tert.-leucine by Ehrlich ascites-tumor cells. The cells were incubated as $4 \%$ suspensions in I $\mathrm{mM} \mathrm{L}-$ or D-tert.-[I-14C]leucine. The distribution ratio represents the ratio of radioactivity per kilogram cellular water, to the radioactivity per liter suspending solution.

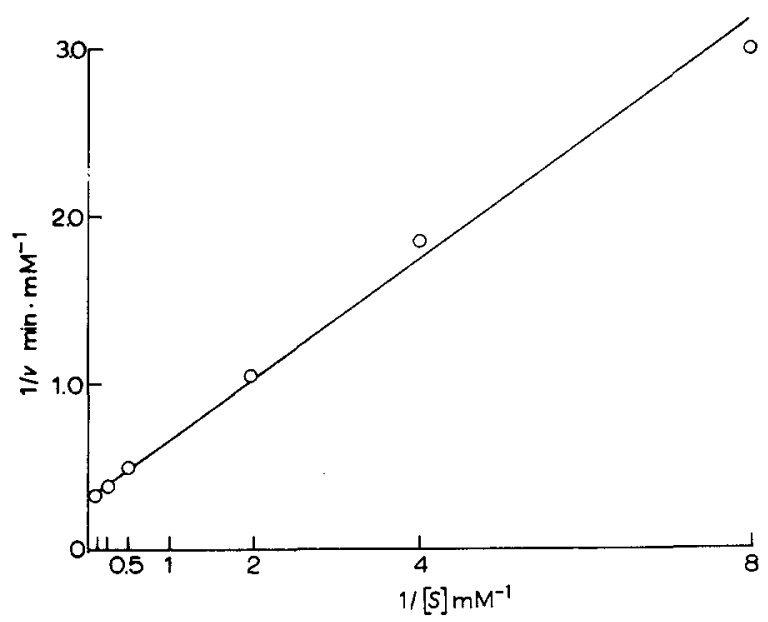

Fig.4. Lineweaver-Burk plot of L-tert.-leucine concentrations against its rate of uptake by Ehrlich cells. See text for details. $V_{\mathrm{max}}, 3.0 \mu \mathrm{moles} / \mathrm{ml} / \mathrm{min} ; K_{\mathrm{m}}, \mathrm{I} .0^{\cdot 10^{-3}} \mathrm{M}$.

complete at $30 \mathrm{~min}$, whereas even at $2 \mathrm{~h}$ the distribution ratio for the $\mathrm{D}$ isomer is still rising, a contrast observed for a number of $D$ and $L$ pairs ${ }^{14,15}$. By approaching the steady state distribution ratio from above, using cells first loaded with the $\mathrm{D}$ isomer, and by successively readjusting the level chosen, a steady-state value of $3.4 \mathrm{mM}$ for the apparent cellular concentration was obtained at a I mM external level.

Fig. 4 shows a plot of the reciprocal of the velocity of uptake versus the reciprocal of the L-tert.-leucine concentration. This plot yields an apparent $K_{\mathrm{m}}$ of Io $^{-3} \mathrm{M}$ and a $V_{\max }$ of $3 \mathrm{mmoles} / 1 / \mathrm{min}$. The latter value is close to that shown by L-leucine ${ }^{16}$. 
Test of inhibition by D-tert.-leucine gave an approximate value for its apparent $K_{1}$ of $0.12 \mathrm{M}$. The corresponding value for $\mathrm{D}$-valine acting on $\mathrm{L}$-valine is o. Io $\mathrm{M}$ (see ref. I6).

The above results show that the living organism discriminates in a normal fashion between the $\mathrm{D}$ and the $\mathrm{L}$ isomers of an amino acid, even though the molecule is largely stable to metabolic attack. The results also show that tert.-leucine is a comparatively specific model solute for studying in isolation the so-called leucine-preferring mediation of transport of neutral amino acids ${ }^{\mathbf{8}, 16}$.

\section{ACKNOWLEDGEMENTS}

This investigation was supported in part by a grant $(\mathrm{C}-2645-\mathrm{C} 6)$ from the National Cancer Institute, National Institutes of Health.

\section{REFERENCES}

1 F. Knoop and N. OKada, Pfüger's Arch. Ges. Physiol, 201 (1923) 3.

2 H. D. DAKIN, J. Biol. Chem., 67 (I926) 34 I.

3 H. D. DAKIN, Am. Chem.J., 44 (IgIO) 48.

4 E. Abderhalden, W. Faust and E. HaAse, Z. Physiol. Chem., 228 (1934) I 87.

5 F. H. SNyder and R. C. Corley, J. Biol. Chem., II 2 (I937-38) 49 I.

${ }^{6}$ M. F. Milligan, Thesis, with R. C. Corley, Purdue University, I942.

7 N. Izumiya, S. J. Fu, S. M. Birnbaum and J. P. Greenstein, J. Biol. Chem., 205 (I953) 22 I.

8 D. L. OXender and H. N. Christensen, Natuve, I97 (196́3) 765.

${ }^{9}$ F. Knoop and J. Landmann, Z, Physiol. Chem., 89 (I9I4) I 57.

10 H. N. Christensen and J. C. Jones, J. Biol. Chem., 237 (I962) i 203.

$11 \mathrm{H}$. N. Christensen and J. B. Clifford, Biochim. Biophys. Acta, 6z (1962) I60.

$12 \mathrm{H}$. N. Christensen ANd T. R. Riggs, J. Biol. Chem., I94 (I952) 57.

13 C. R. Houck, Am. J. Physiol., I 53 (I948) I69.

14 H. N. Christensen, Advan. Protein Chem., I 5 (1960) $239,276$.

15 H. N. Christensen, Biological Transport, Benjamin, New York, I962.

16 D. L. Oxender and H. N. Christensen, J. Biol. Chem., 238 (1963), in the press. 